\title{
TOWARDS SUSTAINABLE HERITAGE AND THE FUTURE OF HERITAGE PRESERVATION "ANALYTICAL STUDY OF PRINCE TAZ PALACE"
}

Eman Ahmed Al-Sayed Mahmoud AL-AKABY*

Decor Department, Faculty of Fine Arts, Alexandria University, Egypt

\begin{abstract}
Heritage has been a component of social cohesion, cultural integration, and identity. Therefore, the preservation of heritage supports the understanding of the past, present and transferring it to future generations, which necessitated the prevention of the demolition of historic buildings to remain as a gateway to the fundamental identity. The conservation of old buildings has either been restored and preserved the artistic and historical heritage, protecting the historical distinguished elements and the recent use of the historical building. The conservation of energy and the safety requirements, as well as economic benefits through good tourism management, So, There was a need for a methodology for sustainable assessment of the heritage environment in order to estimate the urban values associated with history which emphasizes the aesthetic values of the fundamentalism. Therefore, the research comes to study the aspects of preservation of heritage and orientation to sustainable thought or "Heritage Sustainability", which is defined as a future of conservation of heritage. Sustainability is a term that inherent in historical buildings' location, design, interior solutions, and raw materials used to adapt to climate and local environment when the technological progress hadn't been existed. Therefore, the research will be an analytical study of historical architecture and palaces in Cairo, and an attempt to shed light on the important role that preservation of heritage can play in achieving sustainability goals answering questions about how these standards move to present, how to deal with them without harming the environment and the possibility of re-use them optimally.

Keywords

Heritage Conservation, Heritage Sustainability, Sustainable Development, Sustainability of Heritage Tourism.
\end{abstract}

\section{Introduction}

"Inheritance in the Renaissance concept is the title of the presence of the father in the son, the presence of the ancestors in the back, and the past in the present." This is what the comparison made by Al-Jabri on the psychological basis of Freudianism between "inheritance and inheritance" in the old and between "heritage" In its modern renaissance concept. And this was the main inspiration for this research paper as an inductive analytical study that begins with identifying the meaning of heritage and the importance of heritage identity and the importance of bringing it from the past to the present through preservation, revitalization and reuse while preserving the character and revelation, and utilizing it as a form of sustainability, Which is known as heritage sustainability through an analytical study of Prince Taz's palace in Cairo, which has won several attempts to preserve and revive it and preserve its structure and identity amid the city's discontent and overcrowding, so it is a symbol of the presence of the past in the present.

\footnotetext{
*Corresponding author: finea-dean@ alexu.edu.eg
} 
Although change is a necessity for natural development over time, the heritage and its relationship to the heritage identity remains the relationship of the past with the present and how it is present as a kind of sustainability, as cherishing and preserving the heritage is a sacred responsibility. An emotional tendency, meaning reaction, but an inherent instinct that resides in the human psyche. Therefore, the heritage identity represents the communication and transmission of that ancient and the commitment to preserving the spiritual values by preserving the formal and design values of that heritage, but rather it is a reflection or evidence of some of the historical events that the country has gone through, as is much of Cairo's heritage palaces and Also, what is the incident in the example to be studied analytically "Prince Taz Palace" as one of the heritage buildings that expressed important periods that passed through Egyptian history, as this palace began to be designed as a luxurious residential building befitting a prince of great importance in the Mamluk era, so the palace bears all the features of sustainable Mamluk Islamic design It reflects the extent of architectural luxury and attention to the design details of the interior architecture in residential spaces, and then after that it was transformed in the era of Muhammad Ali Pasha to be used in some purposes for the army and the military to demonstrate the great interest in that period in building a strong army and supporting its military tools, to turn after that in the century The nineteenth to a girls' school to inform about a period in which the participation of Egyptian women in the field of work began to focus on awareness of girls 'education, which was known as the Enlightenment era. Then comes the interest of the Ministry of Education and Endowments have been maintained and restored over the past periods, until it is now transformed into one of the cultural palaces that takes care of holding parties, workshops for children, art exhibitions, and seminars. All these periods led to the addition or change of some parts due to the different spatial functions of the palace spaces, while it kept its original identity indicative of the Islamic architecture in Cairo, as the attempts to hold it approached nine times throughout its history, by talking about Islamic Cairo, or in other words what characterized the heritage palaces In Cairo, especially the palace of Prince Taz, with its Arab Islamic style, which is the cultural and civilizational legacy in which the authentic Arab identity is formed. Therefore, it was important to preserve that identity and discover the foundations of its survival and uniqueness, which is what is represented in the details of the design of the interior architecture, including the buildings, spaces, sculptures, pictures and decorations. 


\section{Conculsion}

The revival of historical and heritage buildings is the ideal means for economic, aesthetic and societal development, and even for the urban environment as a whole, where heritage is a product of past civilizations and human experiences, but rather a reflection of the intellectual, political, historical and societal stages, so that the challenge remains. It is the sustainability of preserving that heritage and integrating it within those continuous changes, and the best example of this is the sustainable preservation of Prince Taz Palace, that palace that represents the Mamluk era and its affiliation with the Islamic architecture in Cairo, and which expresses, in its details and areas, environmental and functional sustainability, as well It went through all stages and aspects of preservation, from rehabilitation, use and revival, as it went through several attempts to restore its parts and prevent deterioration, or add parts or spaces when the various spatial functions changed, and the continuation of its uniqueness and clarity of retaining its first identity, and this is different from the rest of the deficiencies Heritage in Cairo, which may have gone through one of these stages or some of them, remains an attempt to maintain sustainable preservation.

And taking him as an example and a teacher for sustainable evaluation of heritage preservation, increasing community awareness, promoting public taste and preserving the heritage identity of the homeland.

\section{References}

- Rasha Hussein Elsayed MOUSTAFA, THE ROLE OF EDUTAINMENT IN MUSEUMS, LEARN THROUGH PLAY, International Journal of Multidisciplinary Studies in Heritage Research, Vol. 3, No. 1, 2020, pp. 15-19.

- Nevin Mohamed KHALIL, THE ROLE OF THE NUBIAN WOMAN, THE BEARER OF HERITAGE, IN PRESERVING THE CULTURAL IDENTITY, International Journal of Multidisciplinary Studies in Heritage Research, Vol. 3, No. 1, 2020, pp. 20-26.

- Maher Ibrahim Muhammad Ismail AL-SAFTI, THE SCIENTIFIC FOUNDATIONS FOR THE RESTORATION AND CONSERVATION OF HERITAGE FACILITIES (ALZA'FAREN PALACE), International Journal of Multidisciplinary Studies in Heritage Research, Vol. 3, No. 1, 2020, pp. 27-31.

Received: September 17, 2020

Accepted: November 28, 2020 